\title{
Catalytic Spectrophotometric Determination of Vanadium in Seawaters Based on the Bromate Oxidative Coupling Reaction of Metol and 2,3,4-Trihydroxybenzoic Acid
}

\author{
Ashraf A. MoHAmeD ${ }^{\dagger}$ and Khalid F. FAwY \\ Department of Chemistry, Faculty of Science, Ain Shams University, Abbassia, Cairo-11566, Egypt
}

\begin{abstract}
A new, simple, sensitive and selective catalytic method is developed for the determination of vanadium in natural and sea waters. The method is based on the catalytic effect of $\mathrm{V}^{\mathrm{V}}$ and/or $\mathrm{V}^{\mathrm{IV}}$ on the bromate oxidative-coupling reaction of metol with 2,3,4-trihydroxybenzoic acid (THBA). The reaction is followed spectrophotometrically by tracing the oxidation product at $380 \mathrm{and} /$ or $570 \mathrm{~nm}$ after $5 \mathrm{~min}$ of mixing the reagents. The optimum reaction conditions are $6.4 \times 10^{-3} \mathrm{~mol}^{-1}$ of metol, $2.0 \times 10^{-3} \mathrm{~mol} \mathrm{l}^{-1}$ of THBA and $0.16 \mathrm{~mol} \mathrm{l}^{-1}$ of bromate at $35^{\circ} \mathrm{C}$ and in the presence of an activator-buffer solution of $1 \times 10^{-2} \mathrm{~mol} \mathrm{l}^{-1}$ of tartrate $(\mathrm{pH}=3.10)$. Following the recommended procedure, $\mathrm{V}^{\mathrm{V}}$ and/or $\mathrm{V}^{\mathrm{IV}}$ can be determined with linear calibration graphs up to $0.75 \mathrm{ng} \mathrm{ml}^{-1}$ and detection limits, based on the $3 \mathrm{~S}_{\mathrm{b}}$ criterion, of 0.008 and $0.018 \mathrm{ng} \mathrm{ml}^{-1}$ at 380 and $570 \mathrm{~nm}$, respectively. The developed method was successfully applied, without any separation or preconcentration processes, to the determination of vanadium in natural and seawaters following the direct calibration and standard addition techniques, respectively.
\end{abstract}

(Received January 30, 2001; Accepted April 5, 2001)

Vanadium in the hydrosphere was believed to be a conservative element due to its almost uniform distribution in both oceanic and limnetic areas. ${ }^{1-3}$ However, slight seasonal variations with the depth of water might be encountered due to biological processes and/or the geochemical cycles of particulate vanadium and phosphorus., ${ }^{4,5}$ Yet few methods have been reported for vanadium determination in seawaters, probably due to the complex matrices involved and/or the high salinity of such samples. Namely, ICP-MS, ${ }^{6,7}$ ICP-AES, ${ }^{8,9}$ NAA, ${ }^{10,11}$ $\mathrm{AAS}^{12,13}$ and HPLC ${ }^{14,15}$ methods were reported with typical detection limits of $0.01-0.04,0.02-0.30,0.03-0.80,0.32$ 0.51 and $0.03-0.2 \mathrm{ng} \mathrm{ml}^{-1}$, respectively. However, the relatively high instrumental $\operatorname{costs}^{6-11}$ and the need for preconcentration, ${ }^{6,7,14}$ chromatographic separation, ${ }^{6,7,9}$ extraction $^{8,10,13,14}$ or coprecipitation ${ }^{11}$ are common disadvantages. On the other hand, catalytic methods of analysis ${ }^{16-28}$ that require simple and low-cost instrumentation usually offer enhanced sensitivities with typical detection limits of $0.1-1.0 \mathrm{ng} \mathrm{ml}^{-1}$. Of these methods, the gallic acid-persulfate standard method ${ }^{19,20}$ and its modifications $\mathrm{s}^{21-23}$ can detect as low as $1 \mathrm{ng} \mathrm{ml}^{-1}$ of $\mathrm{V}^{\mathrm{V}}$. However, due to its limited tolerability of chloride ions, the modified method $^{23}$ was applied to seawaters only after evaporating the sample in the presence of concentrated $\mathrm{H}_{2} \mathrm{SO}_{4} / \mathrm{HClO}_{4}$ mixture to remove the interfering chlorides. Therefore, the need for a simple, sensitive and selective method for application to seawaters is desirable.

The present work describes, for the first time, the determination of $\mathrm{V}^{\mathrm{V}}$ and/or $\mathrm{V}^{\mathrm{IV}}$ down to $0.008 \mathrm{ng} \mathrm{ml}^{-1}$ based on its catalytic effect on the bromate-oxidative coupling reaction of

To whom correspondence should be addressed.

Present address: Department of Chemistry, Faculty of Science, King Khalid University, Abha-9033, Kingdom of Saudi Arabia. E-mail: aamohamd@hotmail.com metol with THBA. The simplicity, selectivity and enhanced sensitivity of the developed method allowed the analysis of natural and seawaters without any separation or preconcentration processes.

\section{Experimental}

\section{Apparatus}

Absorbance measurements were made on a pre-calibrated Shimadzu-1601 (Kyoto, Japan) double beam UV-Visible spectrophotometer equipped with a multi $\lambda$-photometric program pack and $10 \mathrm{~mm}$ matched cells. The cell compartment of the spectrophotometer was thermostatically controlled by circulating water from a PolyScience thermostated water bath (IL, USA) with a temperature stability of $\pm 0.1{ }^{\circ} \mathrm{C}$. Eppendorf vary-pipettes $10-100$ and $100-1000 \mu \mathrm{l}$ (Westbury, NY, USA) were used to deliver accurate volumes. A calibrated EDT Model GP 353, pH-mV meter equipped with an EDT combined glass electrode (EDT Instrument Ltd., Dover Kent, UK) was used for $\mathrm{pH}$ measurements with an accuracy of \pm 0.01 . All glassware and storage bottles were soaked in $10 \%$ nitric acid overnight and thoroughly washed with fresh distilled, deionized water prior to use.

\section{Reagents}

All reagents were of analytical grade and were used as received. Fresh distilled, deionized water was used throughout.

A stock standard solution of $1000 \mathrm{mg} \mathrm{l}^{-1}$ of $\mathrm{V}^{\mathrm{V}}$ was prepared ${ }^{20}$ from $\mathrm{NH}_{4} \mathrm{VO}_{3}$ (Aldrich) and a stock standard $1000 \mathrm{mg} \mathrm{l}^{-1}$ of $\mathrm{V}^{\mathrm{IV}}$ solution was purchased from Fluka. Working standard solutions of $5.0 \mathrm{ng} \mathrm{ml}^{-1}$ of $\mathrm{V}^{\mathrm{V}}$ or $\mathrm{V}^{\mathrm{IV}}$ were freshly prepared from their corresponding stocks (in $1 \times 10^{-2} \mathrm{~mol} \mathrm{l}^{-1}$ of sulfuric acid).

A working standard solution of $2.00 \mathrm{~mol} \mathrm{l}^{-1}$ of sodium 


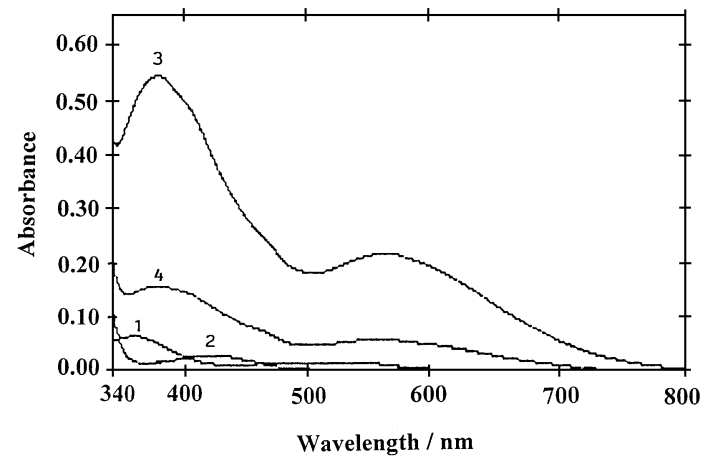

Fig. 1 Absorption spectra of the oxidation products of: 1, metol; 2, THBA; 3 and 4, metol plus THBA, in the presence of bromate. 1, 2 and 3 , in the presence of $0.5 \mathrm{ng} \mathrm{ml}^{-1}$ of $\mathrm{V}^{\mathrm{v}} ; 4$, in the absence of vanadium. Other conditions were those given in the recommended procedure.

bromate was prepared by dissolving the reagent (Aldrich) in water.

A working solution of $8.0 \times 1^{-2} \mathrm{~mol} \mathrm{l}^{-1}$ metol was prepared by dissolving 4-methylaminophenol hemisulfate (Sigma) in $10 \mathrm{ml}$ of $0.05 \mathrm{~mol} \mathrm{l}^{-1}$ phosphoric acid in an ultrasonic bath. The resulting solution is diluted with water in a $50 \mathrm{ml}$ calibrated flask, wrapped with an aluminium foil and stored at $4{ }^{\circ} \mathrm{C}$, when not in use. This solution is stable for at least two days and it should be replaced when a red tint became apparent.

A working solution of $1 \times 10^{-2} \mathrm{~mol} \mathrm{l}^{-1}$ THBA was prepared by dissolving 2,3,4-trihydroxybenzoic acid (Aldrich) in water in an ultrasonic bath. The resulting solution is made up to $50 \mathrm{ml}$ in a calibrated flask, wrapped with an aluminium foil and stored at $4^{\circ} \mathrm{C}$, when not in use. This reagent is stable for at least one week.

An activator-buffer solution was prepared by dissolving 0.75 $\mathrm{g}$ of $\mathrm{L}(+)$-tartaric acid (Merck) in about $90 \mathrm{ml}$ of water, adjusting the $\mathrm{pH}$ to $3.10 \pm 0.02$ with $\mathrm{NaOH}$ and diluting to the mark in a $100 \mathrm{ml}$ calibrated flask.

A working $3.0 \mathrm{~mol} \mathrm{l}^{-1}$ solution of sodium chloride was also prepared by dissolving the Suprapure reagent (Merck) in water.

In the study of interfering species, cations were generally in the form of nitrate or sulfate. Anions were in the form of sodium, potassium or ammonium salts.

\section{Recommended procedure}

Pyrex grade A, $20 \mathrm{ml}$, stoppered glass test tubes were kept at $35^{\circ} \mathrm{C}$ in the thermostated water bath. To one of the test tubes transfer a suitable portion of the unknown natural or seawater sample. To the tube containing seawater, add a suitable amount of the working sodium chloride solution to give a final chloride concentration of $0.25 \pm 0.05 \mathrm{~mol} \mathrm{l}^{-1}$. Dilute with water to 2.20 $\mathrm{ml}$ and add $1.00 \mathrm{ml}$ buffer, $1.00 \mathrm{ml}$ THBA and $0.40 \mathrm{ml}$ metol solution. Shake and place the tube in the thermostated water bath at $35^{\circ} \mathrm{C}$ for $10 \mathrm{~min}$. Add $0.40 \mathrm{ml}$ of sodium bromate, shake well and immediately transfer a portion of the reacting mixture to the spectrophotometric cell to record the absorbance after 5 min at 380 and/or $570 \mathrm{~nm}$ against water as a reference. (The multi $\lambda$-photometric program pack of the spectrophotometer enables the instantaneous monitoring of absorbances at the selected wavelengths). The vanadium concentration of unknown natural water is determined from a calibration graph similarly prepared with the working standard vanadium solution whereas that of seawater was determined using the standard addition technique.
Table 1 Effects of different activators on the reaction system ${ }^{\mathrm{a}}$

\begin{tabular}{|c|c|c|c|c|c|}
\hline \multirow{2}{*}{ Activator } & \multirow{2}{*}{$\begin{array}{c}\text { Conc. } \times 10^{3 /} \\
\mathrm{mol} \mathrm{l}^{-1}\end{array}$} & \multicolumn{2}{|c|}{$A_{570 \mathrm{~nm}}$} & \multicolumn{2}{|c|}{$A_{380 \mathrm{~nm}}$} \\
\hline & & $A_{\mathrm{c}}$ & $A_{\mathrm{u}}$ & $A_{\mathrm{c}}$ & $A_{\mathrm{u}}$ \\
\hline Without & - & 0.162 & 0.062 & 0.412 & 0.155 \\
\hline \multirow{2}{*}{ Tartaric acid } & 5 & 0.213 & 0.061 & 0.527 & 0.160 \\
\hline & 10 & 0.217 & 0.061 & 0.535 & 0.164 \\
\hline \multirow{2}{*}{ Citric acid } & 5 & 0.170 & 0.056 & 0.469 & 0.154 \\
\hline & 10 & 0.178 & 0.058 & 0.482 & 0.156 \\
\hline \multirow[t]{2}{*}{ Succinic acid } & 5 & 0.196 & 0.047 & 0.470 & 0.166 \\
\hline & 10 & 0.198 & 0.047 & 0.460 & 0.163 \\
\hline Malonic acid ${ }^{\mathrm{b}}$ & 5 & 0.188 & 0.059 & 0.462 & 0.163 \\
\hline Nicotinic acid ${ }^{b}$ & 5 & 0.201 & 0.063 & 0.512 & 0.168 \\
\hline \multirow[t]{2}{*}{ Salicylic acid } & 5 & 0.205 & 0.062 & 0.510 & 0.163 \\
\hline & 10 & 0.203 & 0.066 & 0.493 & 0.165 \\
\hline \multirow[t]{2}{*}{ 5-Sulfosalicylic acid } & 5 & 0.176 & 0.062 & 0.478 & 0.151 \\
\hline & 10 & 0.173 & 0.065 & 0.468 & 0.159 \\
\hline \multirow[t]{2}{*}{ 8-Hydroxyquinoline sulfate } & e 1 & 0.166 & 0.056 & 1.696 & 1.431 \\
\hline & 5 & 0.129 & 0.060 & 2.911 & 2.872 \\
\hline Tiron $^{\mathrm{b}}$ & 5 & 0.158 & 0.059 & 0.454 & 0.160 \\
\hline
\end{tabular}

a. Except for the activator's type and concentration, other conditions and symbols were those given in the recommended procedure. b. Higher concentrations gave too low $A_{\mathrm{c}}$ values.

\section{Results and Discussion}

Metol was frequently applied to the analysis of some pharmaceutical compounds, ${ }^{29-31}$ however, THBA had almost no analytical applications. Preliminary experiments showed that metol and THBA may be slowly oxidized by acidic bromate to give red and orange oxidation products, showing absorption maxima at 360 and $420 \mathrm{~nm}$, respectively (Fig. 1, curves 1,2). However, bromate oxidation of a mixture of metol and THBA gave a yellow-orange oxidative coupling product that exhibited two strong absorption maxima at 380 and $570 \mathrm{~nm}$, respectively, where the former peak showed a much higher intensity (Fig. 1, curve 4). Vanadium exerted a pronounced catalytic effect on that oxidative coupling reaction (Fig. 1, curve 3). The positions of the two absorption maxima were essentially stable even with changing the reaction conditions. However, the initial parts of the obtained $A-t$ graphs showed poor linearity. Therefore, fixed time measurements at 380 and/or $570 \mathrm{~nm}, 5$ min after starting the reaction, was adopted in the recommended procedure to provide a moderate sensitivity and a low blank reading.

Some coupling agents, such as monohydric-, dihydric- and trihydric phenols were tested as coupling agents in the bromate oxidation of metol. The oxidative coupling products obtained with trihydric phenol gave higher sensitivities compared with those obtained with monohydric- and dihydric phenols. The following absorbance values were obtained with the tested trihydric phenols at the respective wavelengths: chloroglucinol $(0.060,365 \mathrm{~nm}$; 0.117, $464 \mathrm{~nm})$; pyrogallol $(0.239,362 \mathrm{~nm}$; $0.072,540 \mathrm{~nm})$; gallic acid $(0.290,352 \mathrm{~nm} ; 0.138,567 \mathrm{~nm})$; THBA $(0.534,380 \mathrm{~nm} ; 0.217,570 \mathrm{~nm})$. Therefore, THBA was selected for further studies.

\section{Optimization of the reaction variables}

The absorbances of the catalyzed and uncatalyzed reactions, $A_{\mathrm{c}}$ and $A_{\mathrm{u}}$, decreased gradually with $\mathrm{pH}$ in the range of $2.20-$ 3.90; however, the sensitivity $\left(A_{\mathrm{c}}-A_{\mathrm{u}}\right)$ remained almost constant in the $\mathrm{pH}$ range of $3.0-3.2$. Thus, in order to provide moderate sensitivity and a lower reagent blank, a pH of $3.10 \pm$ 0.02 was adopted in the procedure.

The possible activating effects of different activators were investigated at $\mathrm{pH}$ 3.1. Results showed that the best activator 


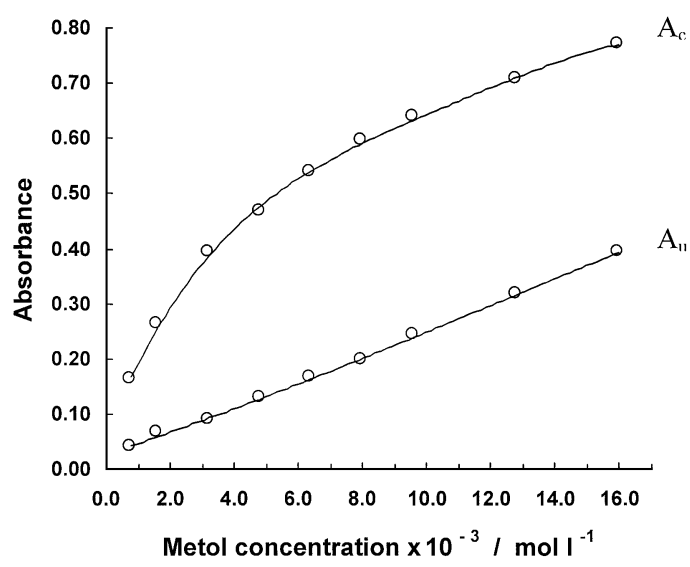

Fig. 2 Effect of metol concentration. $A_{\mathrm{u}}$, uncatalyzed reaction; $A_{\mathrm{c}}$, reaction catalyzed by $0.5 \mathrm{ng} \mathrm{ml}^{-1}$ of $\mathrm{V}^{\mathrm{v}} ; \lambda=380 \mathrm{~nm}$. Except for the abscissa variable, other conditions were as given in the Fig. 1.

for the reaction was tartrate, which gave the highest sensitivity and the lowest blank value (Table 1). Therefore, tartrate was used as an effective activator and a buffer. Moreover, the sensitivity of the reaction was almost constant in the range of $0.5-1.5 \times 10^{-2} \mathrm{~mol} \mathrm{l}^{-1}$ of tartrate. Therefore, a $1 \times 10^{-2} \mathrm{~mol} \mathrm{l}^{-1}$ tartrate $(\mathrm{pH} 3.10 \pm 0.02)$ was adopted in the recommended procedure.

The $A_{\mathrm{c}}$ values increased gradually, whereas $A_{\mathrm{u}}$ values increased almost linearly with metol concentration (Fig. 2). However, the sensitivity was almost constant in the concentration range of $6.4-16.0 \times 10^{-3} \mathrm{~mol} \mathrm{l}^{-1}$ of metol; therefore, a concentration of $6.4 \times 10^{-3} \mathrm{~mol} \mathrm{l}^{-1}$ metol was used in the procedure ( $400 \mu \mathrm{l}$ of the working metol solution) to provide a moderate sensitivity and a low blank reading.

The effect of THBA concentration was tested using $0.1-4.8 \times$ $10^{-3} \mathrm{~mol} \mathrm{l}^{-1}$ of THBA. The absorbances $A_{\mathrm{c}}$ and $A_{\mathrm{u}}$ rapidly increased with concentration up to $1.6 \times 10^{-3} \mathrm{~mol} \mathrm{l}^{-1}$. However, in the THBA concentration range of $1.6-4.8 \times 10^{-3} \mathrm{~mol} \mathrm{l}^{-1}$, the absorbances $A_{\mathrm{c}}$ and $A_{\mathrm{u}}$ and the sensitivity increased very slightly. Therefore, a $2 \times 10^{-3} \mathrm{~mol} \mathrm{l}^{-1}$ of THBA was used in the recommended procedure.

The $A_{\mathrm{c}}$ values increased gradually, whereas $A_{\mathrm{u}}$ values increased almost linearly with bromate concentration in the range of $0.02-0.40 \mathrm{~mol} \mathrm{l}^{-1}$. However, a $0.16 \mathrm{~mol} \mathrm{l}^{-1}$ bromate (400 $\mu \mathrm{l}$ of the working bromate solution) was used in the procedure to provide a moderate sensitivity and a low blank reading.

The absorbances, $A_{\mathrm{c}}$ and $A_{\mathrm{u}}$, increased gradually with temperature; however, a working temperature of $35^{\circ} \mathrm{C}$ was adopted in the recommended procedure because of its moderate sensitivity and reagent blank and its convenience for operation.

The absorbance of the uncatalyzed reaction, $A_{\mathrm{u}}$, showed a slight dependence on the order of mixing the reagents. For example, addition of bromate to metol (or THBA) alone gave high blank values that may be attributed to the involvement of metol (or THBA) and bromate in a process other than the oxidative coupling reaction. Therefore, bromate was added as the last reagent in the recommended procedure.

The effects of potential interferents which generally accompany vanadium in natural and seawaters were studied. The maximum tolerable concentrations of 65 foreign species are shown in Table 2. The tolerance level was defined as the concentration of foreign species, $\mathrm{mg} \mathrm{l}^{-1}$, that produced a change of less than $5 \%$ in the absorbance of a reaction catalyzed by 0.5
Table 2 Tolerance levels of foreign species in the determination of $0.5 \mathrm{ng} \mathrm{ml}^{-1}$ of vanadium ${ }^{\mathrm{a}}$

\begin{tabular}{|c|c|}
\hline $\begin{array}{l}\text { Tolerance } \\
\text { level/ } \mathrm{mg} \mathrm{l}^{-}\end{array}$ & Foreign species ${ }^{\mathrm{b}}$ \\
\hline$>2000$ & acetate, $\mathrm{H}_{2} \mathrm{PO}_{4}^{-},{ }^{\mathrm{c}} \mathrm{NO}_{3}{ }^{-}, \mathrm{ClO}_{4}{ }^{-},{ }^{\mathrm{c}} \mathrm{SO}_{4}{ }^{2-},{ }^{\mathrm{c}} \mathrm{Na}^{+}, \mathrm{K}^{+}, \mathrm{NH}_{4}{ }^{+}, \mathrm{Cd}^{\mathrm{II}}$ \\
\hline 500 & $\mathrm{As}^{\mathrm{V}}, \mathrm{Mn}^{\mathrm{II}}$ \\
\hline 300 & $\mathrm{Cl}^{-},{ }^{\mathrm{c}} \mathrm{Ca}^{\mathrm{II}}, \mathrm{Mg}^{\mathrm{II}}, \mathrm{Sb}^{\mathrm{V}}, \mathrm{H}_{3} \mathrm{BO}_{3}$ \\
\hline 100 & $\mathrm{As}^{\mathrm{III}},{ }^{\mathrm{c}} \mathrm{Sb}^{\mathrm{III}},{ }^{\mathrm{c}} \mathrm{Ce}^{\mathrm{III}}, \mathrm{Li}^{\mathrm{I}}, \mathrm{Pb}^{\mathrm{II}}, \mathrm{Sr}^{\mathrm{II}}, \mathrm{Tl}^{\mathrm{I}}$ \\
\hline 50 & $\mathrm{~F}^{-},{ }^{\mathrm{c}} \mathrm{Be}^{\mathrm{II}}, \mathrm{La}^{\mathrm{III}}, \mathrm{Th}^{\mathrm{IV}}, \mathrm{W}^{\mathrm{VI}}$ \\
\hline 10 & $\mathrm{Br}-,{ }^{\mathrm{c}} \mathrm{Bi}^{\mathrm{III}}, \mathrm{Co}^{\mathrm{II}}, \mathrm{Ni}^{\mathrm{II}}, \mathrm{U}^{\mathrm{VI}},{ }^{\mathrm{c}} \mathrm{Zn}^{\mathrm{II}}$ \\
\hline 5 & $\mathrm{SO}_{3}^{2-}, \mathrm{S}_{2} \mathrm{O}_{5}^{2-}, \mathrm{Cu}^{\mathrm{II}}, \mathrm{Hg}^{\mathrm{II}}$ \\
\hline 2 & $\mathrm{I}^{-},{ }^{\mathrm{c}} \mathrm{NO}_{2}^{-},{ }^{-} \mathrm{P}_{2} \mathrm{O}_{7}{ }^{4-},{ }^{\mathrm{c}} \mathrm{SCN}^{-},{ }^{\mathrm{c}} \mathrm{Sn}^{\mathrm{II}},{ }^{\mathrm{c}} \mathrm{Sn}^{\mathrm{IV}}$ \\
\hline 1 & $\begin{array}{l}\text { CyDTA, }{ }^{c}{ }^{c}{ }_{3}^{-} \text {, oxalate, }{ }^{c} \text { thiourea, }{ }^{\mathrm{c}} \mathrm{Ag}^{\mathrm{I}}, \mathrm{Al}^{\mathrm{III}}, \mathrm{Ce}^{\mathrm{IV}}, \\
\mathrm{Hf}^{\mathrm{IV}}, \mathrm{Mn}^{\mathrm{VII}},{ }^{\mathrm{c}} \mathrm{Mo}^{\mathrm{VI}}, \mathrm{Nb}^{\mathrm{V}},{ }^{\mathrm{c}} \mathrm{Pd}^{\mathrm{II}}, \mathrm{Pt}^{\mathrm{IV}}, \mathrm{Ta}^{\mathrm{V}},{ }^{\mathrm{c}} \mathrm{Ti}^{\mathrm{IV}}, \mathrm{Zr}^{\mathrm{IV}} \mathrm{c}\end{array}$ \\
\hline 0.5 & DTPA, ${ }^{c}$ EDTA $,{ }^{c} \mathrm{Au}^{\mathrm{III}}, \mathrm{Cr}^{\mathrm{III}}, \mathrm{Cr}^{\mathrm{VI}}$ \\
\hline 0.1 & $\mathrm{Fe}^{\mathrm{III}}$ \\
\hline
\end{tabular}

a. Reaction conditions were those given in the recommended procedure.

b. Ions suspected to have buffering actions were adjusted to the working $\mathrm{pH}$ before studying their effects.

c. Ions producing negative interferences.

ng $\mathrm{ml}^{-1}$ of $\mathrm{V}^{\mathrm{v}}$. Tolerance levels were almost the same for measurements made at 380 and $570 \mathrm{~nm}$, respectively. The reported concentration levels of common pollutants ${ }^{3,20}$ in natural and seawaters are generally orders of magnitude lower than their tolerance levels shown in Table 2, indicating the high selectivity of the developed method. The mean iron concentration $^{3,26}$ in seawater is $0.04 \mathrm{ng} \mathrm{ml}^{-1}$, which is much lower than its tolerance limit; therefore, its interference is negligible in the analysis of such waters. However, such a tolerance level may be exceeded in some polluted waters but simple dilution renders this effect harmless.

Linear calibration graphs $(r \leq 0.9997)$ up to $0.75 \mathrm{ng} \mathrm{ml}^{-1}$ of $\mathrm{V}^{\mathrm{V}}$ and/or VIV were obtained, following the recommended procedure. The least square's equations for the calibration graphs were:

$$
\begin{array}{ll}
A=0.165+0.754[\mathrm{~V}] & \text { at } 380 \mathrm{~nm} \\
A=0.061+0.312[\mathrm{~V}] & \text { at } 570 \mathrm{~nm}
\end{array}
$$

where [V] is the $\mathrm{V}^{\mathrm{V}}$ and/or $\mathrm{V}^{\mathrm{IV}}$ concentration expressed in $\mathrm{ng}$ $\mathrm{ml}^{-1}$. The detection limits, based on the $3 S_{\mathrm{b}}$-criterion, were 0.008 and $0.018 \mathrm{ng} \mathrm{ml}^{-1}$ of $\mathrm{V}$ at 380 and $570 \mathrm{~nm}$, respectively.

Five replicate determinations of $0.05,0.35$ and $0.70 \mathrm{ng} \mathrm{ml}^{-1}$ of $\mathrm{V}^{\mathrm{IV}}$ or $\mathrm{V}^{\mathrm{v}}$, following the recommended procedure, gave recoveries $\geq 98.5 \%$ with relative standard deviations of $\leq 1.1$. This indicates the high accuracy and precision of the developed method and shows that it is equally applied to the determination of both $\mathrm{V}^{\mathrm{V}}$ and/or $\mathrm{V}^{\mathrm{IV}}$ without any pretreatment. Moreover, the student's $t$-test values were $\leq 1.3$, showing that the $t$-test could not detect any systematic error in the developed method. (The tabulated $t$-value for the $95 \%$ confidence level and $n=5$ is 2.78). ${ }^{32}$

Seawaters are of high salinity, usually containing about $3 \%$ chlorides. $^{3} \quad$ Therefore, the effects of added salts were investigated using Suprapure $\mathrm{NaCl}, \mathrm{NaNO}_{3}$ and $\mathrm{Na}_{2} \mathrm{SO}_{4}$ reagents (Merck) and produced the different trends shown in Fig. 3. Sodium chloride exerted a serious inhibitory effect up to a concentration of $0.2 \mathrm{~mol} \mathrm{l}^{-1}$; however, it had almost no further effect up to $0.4 \mathrm{~mol} \mathrm{l}^{-1}$. On the other hand, the effects of nitrate and sulfate are not harmful, since their levels in seawaters ${ }^{3}$ are 
Table 3 Determination of vanadium in natural and seawaters ${ }^{\mathrm{a}}$

\begin{tabular}{|c|c|c|c|c|c|c|}
\hline \multirow{2}{*}{$\begin{array}{l}\text { Sample } \\
\text { No. }\end{array}$} & \multirow{2}{*}{$\begin{array}{c}\text { Taken/ } \\
\mathrm{ml}^{\mathrm{b}}\end{array}$} & \multirow[b]{2}{*}{ Absorbance at $380 \mathrm{~nm}$} & \multicolumn{2}{|c|}{ Vanadium/ng ml ${ }^{-1 \mathrm{c}}$} & \multirow[b]{2}{*}{$\underset{\%}{\mathrm{RSD}}$} & \multirow[b]{2}{*}{$\begin{array}{c}\text { Recovery, } \\
\%\end{array}$} \\
\hline & & & Added & $\begin{array}{c}\text { Found } \pm \\
\text { S. D. }\end{array}$ & & \\
\hline \multicolumn{7}{|c|}{ Natural waters } \\
\hline \multirow[t]{2}{*}{1} & 2.000 & $0.397,0.398,0.399,0.401,0.401$ & - & $1.553 \pm 0.012$ & 0.8 & - \\
\hline & 2.000 & $0.548,0.549,0.551,0.551,0.552$ & 1.000 & $2.554 \pm 0.011$ & 0.4 & 100.1 \\
\hline \multirow[t]{2}{*}{2} & 2.000 & $0.248,0.250,0.250,0.251,0.252$ & - & $0.565 \pm 0.010$ & 1.8 & - \\
\hline & 2.000 & $0.398,0.399,0.399,0.401,0.401$ & 1.000 & $1.556 \pm 0.009$ & 0.6 & 99.1 \\
\hline \multirow[t]{2}{*}{3} & 2.000 & $0.184,0.185,0.185,0.187,0.188$ & - & $0.069 \pm 0.005$ & 7.2 & - \\
\hline & 2.000 & $0.486,0.486,0.487,0.488,0.489$ & 1.000 & $1.068 \pm 0.005$ & 0.5 & 99.9 \\
\hline \multirow[t]{2}{*}{4} & 2.000 & $0.177,0.178,0.179,0.180,0.180$ & - & $0.046 \pm 0.004$ & 8.7 & - \\
\hline & 2.000 & $0.479,0.480,0.480,0.481,0.483$ & 1.000 & $1.046 \pm 0.005$ & 0.5 & 100.0 \\
\hline \multicolumn{7}{|c|}{ Seawaters } \\
\hline \multirow[t]{2}{*}{5} & 1.800 & - & - & $1.432 \pm 0.019$ & 1.3 & \\
\hline & $1.000^{\mathrm{d}}$ & & & $\begin{array}{c}1.418 \pm 0.016 \\
\text { Av. }=1.425 \pm 0.025\end{array}$ & 1.1 & \\
\hline \multirow[t]{3}{*}{6} & 1.800 & - & - & $1.403 \pm 0.028$ & 2.0 & - \\
\hline & $1.000^{\mathrm{d}}$ & & & $1.375 \pm 0.012$ & 0.9 & \\
\hline & & & & $A v \cdot=1.390+0.031$ & & \\
\hline \multirow[t]{3}{*}{7} & 1.800 & - & - & $1.213 \pm 0.024$ & 2.0 & - \\
\hline & $1.000^{\mathrm{d}}$ & & & $1.229 \pm 0.012$ & 1.0 & \\
\hline & & & & $A v \cdot=1.221+0.027$ & & \\
\hline
\end{tabular}

a. Conditions and symbols were as given in Table 1. b. Samples $1-4$ were natural waters from the local market; $5-7$ were surface seawaters from El-Dabbaa, Matrouh city, the northwest part of Egypt and collected on 23-1-2000. No. 1, Nubia; 2, Mineral; 3, Safi; 4, AlManar. No. 5, from Tannoum's bay ( $31^{\circ} 02^{\prime} 43.80^{\prime \prime} \mathrm{N}$ and $\left.28^{\circ} 33^{\prime} 49.60^{\prime \prime} \mathrm{E}\right)$; No. 6, from Summer's bay ( $31^{\circ} 03^{\prime} 15.30^{\prime \prime} \mathrm{N}$ and $\left.28^{\circ} 30^{\prime} 32.70^{\prime \prime} \mathrm{E}\right)$; No. 7, from Microwave's bay ( $31^{\circ} 04^{\prime} 14.13^{\prime \prime} \mathrm{N}$ and $\left.28^{\circ} 28^{\prime} 10.20^{\prime \prime} \mathrm{E}\right)$. No. 1,2 were analyzed after 1:1 dilution; No. 3 - 7 were analyzed without dilution. c. Added to or found in the original sample $(n=5)$, before dilution. No. $1-4$ by the direct calibration technique; No. 5 7 by the standard addition technique. d. Analyzed after addition of $0.2 \mathrm{ml}$ of the working $\mathrm{NaCl}$ solution to maintain a chloride concentration of about $0.25 \pm 0.05 \mathrm{~mol} \mathrm{l}^{-1}$.

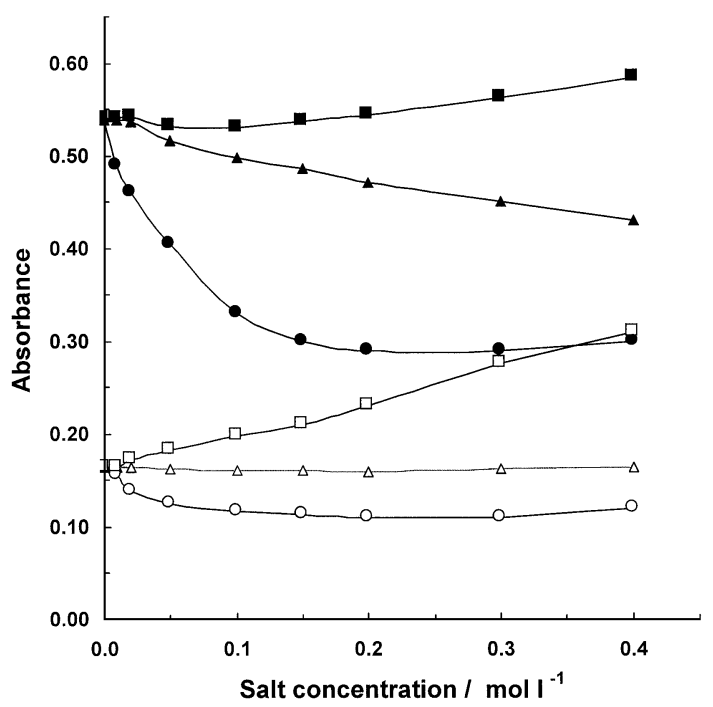

Fig. 3 Effects of added salt concentration on $A_{\mathrm{c}}(\boldsymbol{\square}, \bullet, \boldsymbol{\Delta})$ and $A_{\mathrm{u}}$ $(\square, \circ, \triangle)$ readings. Other conditions were those given in Fig. 1: $\mathrm{NaCl}(\bullet, \bigcirc) ; \mathrm{Na}_{2} \mathrm{SO}_{4}(\boldsymbol{\bullet}, \square)$; and $\mathrm{NaNO}_{3}(\boldsymbol{\Delta}, \Delta)$.

usually much lower than their tolerance limits in the present work. However, seawaters were analyzed following the standard addition technique, where the chloride content in the reaction cell was maintained at $0.25 \pm 0.05 \mathrm{~mol} \mathrm{l}^{-1}$, by adding the appropriate volumes of the working $\mathrm{NaCl}$ solution.
Determination of vanadium in natural and seawaters

Owing to its high sensitivity and selectivity, the developed method was directly applied to the determination of vanadium in natural and seawaters, without any separation or preconcentration processes. Water samples were collected, filtered through $0.45-\mu \mathrm{m}$ Millipore membrane filters of the MFHA type, acidified with $\mathrm{HNO}_{3}$ to $\mathrm{pH}$ of $1.8 \pm 0.2$, stored at $4^{\circ} \mathrm{C}$ and analyzed within $48 \mathrm{~h}$ of collection. Prior to the analysis step, each sample is brought to a working $\mathrm{pH}$ of $3.10 \pm 0.2$. Chloride contents of the analyzed seawaters were determined from argentiometric titrations ${ }^{20}$ and were found to be about 0.65 $\mathrm{mol} \mathrm{l}^{-1}$.

Table 3 shows the analytical results for natural and seawater samples, obtained following the recommended procedure. Recovery experiments were used to check the reliability of the developed method and gave quantitative results $(99.1-100.1)$ with convenient reproducibility (RSD $=0.4-2.0 \%$ ), thus revealing the high accuracy and precision of the developed method.

\section{Conclusion}

In comparison with most instrumental techniques ${ }^{6-15}$ that were usually coupled with prior separation and/or preconcentration processes, the present work describes a new, simple, sensitive, selective and precise method for vanadium determination in natural and seawaters down to $0.008 \mathrm{ng} \mathrm{ml}^{-1}$ using a simple spectrophotometer. On the other hand, among the numerous catalytic methods for vanadium determination, only six methods ${ }^{23-28}$ dealt with seawaters, probably due to the limited sensitivity and/or selectivity of such methods. Table 4 shows 
Table 4 Comparison of catalytic spectrophotometric methods for vanadium determination in seawaters

\begin{tabular}{|c|c|c|c|}
\hline Reaction system & $\begin{array}{l}\text { Linear range } \\
(\mathrm{DL}) / \mathrm{ng} \mathrm{ml}^{-1}\end{array}$ & Remarks & Ref. \\
\hline Gallic acid + persulfate & $4.1-33.3(1.0)$ & $a, b$ & 23 \\
\hline $\begin{array}{l}N \text {-Phenyl- } p \text {-phenylenediamine }+ \\
\quad N, N \text {-dimethylaniline }+ \text { bromate }\end{array}$ & $0.00-1.00$ & $\mathrm{c}$ & 24 \\
\hline $\begin{array}{l}\text { 4-Aminoantipyrine }+N, N- \\
\text { dimethylaniline }+ \text { bromate }\end{array}$ & $0.05-2.00(0.05)$ & $\mathrm{c}$ & 25 \\
\hline $\begin{array}{l}\text { Bindschedler's Green Leuco base + } \\
\text { +bromate }\end{array}$ & $+0.1-0.51(0.001)$ & $\mathrm{d}, \mathrm{e}, \mathrm{f}$ & 26 \\
\hline Leuco Methylene Blue + bromate & $0.0-7.0(0.2)$ & - & 27 \\
\hline Chromotropic acid + bromate & $0.0-2.5(0.02)$ & $\mathrm{c}, \mathrm{d}$ & 28 \\
\hline Metol + THBA + bromate & $0.0-0.75(0.008)$ & This & \\
\hline
\end{tabular}

a. Measurements were made after 60 min of mixing the reagents. b. For preconcentration and elimination of the strong chloride interference, samples were evaporated in the presence of conc. $\mathrm{H}_{2} \mathrm{SO}_{4} / \mathrm{HClO}_{4}$ mixture

c. A prior preconcentration and/or separation step was necessary. d. FIA method.

e. The initial parts of the calibration graph were non-linear.

f. Artificial seawater was used to compensate for matrix interferences

the comparison of linear ranges of these catalytic methods, ${ }^{23-28}$ showing the advantages of the present work.

\section{References}

1. A. W. Morris, Deep-Sea Res., 1975, 22, 49.

2. Y. Nojiri, T. Kawai, A. Otsuki, and K. Fuwa, Water Res., 1985, 19, 508.

3. J. R. Donat and K. W. Bruland, in "Trace Elements in Natural Waters", ed. B. Salbu and E. Steinnes, 1995, CRC Press, Boca Raton, Florida, 247 - 281.

4. R. W. Collier, Nature [London], 1984, 309, 441.

5. R. M. Sherrell and E. A. Boyle, Deep-Sea Res., 1988, 35, 1319.

6. C. C. Wann and S. J. Jiang, Anal. Chim. Acta, 1997, 357, 211.

7. K. L. Yang, S. J. Jiang, and T. J. Hwang, J. Anal. At. Spectrom., 1996, 11, 139.

8. X. J. Li, P. Schramel, H. Z. Wang, P. Grill, and A. Kettrup, Fresenius' J. Anal. Chem., 1996, 356, 52

9. H. Ogura and K. Oguma, Microchem. J., 1994, 49, 220.
10. Y. Sakai, K. Ohshita, K. Tomura, and S. Koshimizu, Bunseki Kagaku, 1994, 43, 919.

11. R. R. Rao and A. Chatt, J. Radioanal. Nucl. Chem., 1993, $168,439$.

12. P. G. Su and S. D. Huang, J. Anal. At. Spectrom., 1998, 13 , 641.

13. A. Adachi, K. Ogawa, Y. Tsushi, N. Nagao, and T. Kobayashi, Water Res., 1997, 31, 1247.

14. Y. Shijo, H. Sato, N. Uehara, and S. Aratake, Analyst [London], 1996, 121, 325

15. H. Ohashi, N. Uehara, and Y. Shijo, J. Chromatogr., 1991, $539,225$.

16. D. Perez-Bendito and M. Silva, "Kinetic Methods in Analytical Chemistry", 1988, Ellis Horwood, Chichester.

17. K. B. Yatsimirskii, "Kinetic Methods of Analysis", 1966 Pergamon Press, Oxford.

18. A. A. Mohamed, M. Iwatsuki, T. Fukasawa, and M. F. ElShahat, Analyst [London], 1995, 120, 2281.

19. M. J. Fishman and M. V. Skougstad, Anal. Chem., 1964, $36,1643$.

20. APHA-AWWA-WEF, "Standard Methods for the Examination of Water and Wastewater", ed. A. E. Greenberg, L. S. Clesceri, and A. D. Eaton, 19th ed., 1995, American Public Health Association, Washington, D. C.

21. Q. Weiguo, Anal. Chem., 1983, 55, 2043.

22. L. Darbha and J. Arunachalam, Talanta, 1993, 40, 135.

23. B. K. Balaji, G. Saravanakumar, P. Murugesan, and G. Mishra, Talanta, 1998, 46, 1299.

24. S. Nakano, E. Kasahara, M. Tanaka, and T. Kawashima, Chem. Lett., 1981, 5, 597.

25. S. Nakano, S. Kinoshita, M. Ikuta, and T. Kawashima, Anal. Sci., 1990, 6, 435.

26. M. Sugiyama and T. Hori, Anal. Chim. Acta, 1992, 261, 189

27. S. Kawakubo, K. Ogihara, M. Iwatsuki, and T. Fukasawa, J. Trace Microprobe Tech., 1997, 15, 189.

28. T. Yamane, Y. Osaka, and M. Suzuki, Talanta, 1998, 45 , 583.

29. C. S. P. Sastry, M. Aruna, and A. R. M. Rao, Talanta, 1988, 35, 23.

30. C. S. P. Sastry, T. T. Rao, A. Sailaja, and J. V. Rao, Talanta, 1991, 38, 1107

31. B. S. Sastry, V. Balakrishna, T. Rama-Rao, K. Rama-Rao, and C. S. P. Sastry, Indian Drugs, 1994, 31, 307.

32. J. C. Miller and J. N. Miller, "Statistics for Analytical Chemistry", 3rd ed., 1993, Ellis Horwood, Chichester. 